\title{
Upaya Meningkatkan Keterampilan Menyimak Dongeng Dengan Penerapan Model Pembelajaran Cooperative Tipe Script Pada Siswa Kelas VII B SMP N 1 Monterado
}

\author{
Heru Susanto ${ }^{1}$ \\ ${ }^{1}$ Program Studi Pendidikan Bahasa dan Sastra Indonesia, STKIP Singkawang, \\ Email: eru_anto@yahoo.co.id
}

\author{
Keywords : \\ menyimak, dongeng, model \\ pembelajaran cooperative tipe \\ script
}

\begin{abstract}
Tujuan dari penelitian ini adalah untuk meningkatkan hasil belajar siswa dalam materi menyimak dongeng dengan menggunakan model pembelajaran Cooperative tipe Script. Masalah yang menjadi fokus dalam penelitian ini adalah bagaimana perencanaan, bagaimana proses pelaksanaan pembelajaran, dan bagaiamana hasil pembelajaran keterampilan menyimak dongeng dengan penerapan model pembelajaran Cooperative tipe Script pada siswa kelas VII B SMP Negeri 1 Monterado. Metode yang digunakan dalam penelitian ini menggunakan metode deskriptif kualitatif yakni bermaksud untuk menyelidiki tentang keadaan objek penelitian yang diteliti. Alat pengumpul data dalam penelitian ini adalah panduan observasi, panduan wawancara, tes dan dokumentasi, sedangkan teknik analisis data menggunakan teknik deskriptif komparatif dan teknik analisis kritis. Hasil dari keseluruhan penelitian dibuktikan dengan peningkatan kemampuan guru dalam mengelola pembelajaran, dan kegiatan dalam partisipasi siswa mengikuti proses pembelajaran. Kinerja guru dalam mengelola pembelajaran pun terus meningkat dari $46,1 \%$ pada siklus I menjadi $84,7 \%$ pada siklus II. Nilai kegiatan aktifitas siswa di kelas mengikuti proses pembelajaran pada siklus I mencapai $64,7 \%$ meningkat menjadi $88,2 \%$ pada siklus II. Hasil pembelajaran dengan menggunakan model pembelajaran Cooperative tipe Script. Peningkatan hasil belajar siswa dapat diketahui setelah membandingkan hasil pra tindakan, siklus I, dan siklus II. Nilai rata-rata yang diperoleh siswa pada pra tindakan adalah 65,9 berada dalam kategori kurang, pada siklus I rata-rata nilai 73,6 berada dalam kategori cukup, dan pada siklus II 88,0 berada dalam kategori baik dan mencapai pada peningkatan yang diharapkan. Kesimpulan dalam penelitian ini adalah penerapan model pembelajaran Cooperative tipe Script dalam penelitian tindakan kelas dapat meningkatkan kualitas proses pembelajaran menyimak dongeng.
\end{abstract}




\section{PENDAHULUAN}

Berdasarkan praobservasi yang dilakukan penulis di sekolah SMP Negeri 1 Monterado Kecamatan Monterado Kabupaten Bengkayang menunjukkan bahwa kemampuan siswa dalam menyimak, khususnya menyimak dongeng sangat kurang. Kemampuan menyimak siswa sangat terbatas, padahal menyimak adalah modal utama bagi siswa untuk menyerap berbagai pengetahuan lainnya di luar mata pelajaran bahasa Indonesia. Menurut Susanto, H., \& Sunarsih, E. (2015) Menyimak merupakan langkah awal dari proses pembelajaran berbahasa. Menyimak juga merupakan keterampilan yang pertama kali dipelajari dan dikuasai manusia. Hal ini berkaitan dengan motivasi siswa yang menyebabkan hasil belajar yang tidak memuaskan. Kemudian dari sisi guru yang berkaitan dengan pemilihan model pembelajaran yang tepat dan efektif sebagai bentuk inovasi dalam hal pembelajaran bahasa Indonesia. Menurut Oktavia, W dan Safrahady (2015) inovasi pembelajaran merupakan sebuah upaya pembaharuan terhadap berbagai komponen yang diperlukan dalam penyampaian materi pelajaran berupa ilmu pengetahuan dari tenaga pendidik kepada para peserta didik dengan tujuan untuk meningkatkan kualitas pendidikan yang berlangsung.

Selain hal tersebut pemilihan media pembelajaran yang dilakukan oleh guru juga mempengaruhi keberhasilan proses pembelajaran. Dari hasil praobservasi yang dilakukan penulis membuktikan di SMP Negeri 1 Monterado, Kecamatan Monterado, Kabupaten Bengkayang, pada kelas VII B siswa yang memperoleh hasil belajar yang rendah pada pelajaran bahasa Indonesia dalam hal ini keterampilan menyimak 19 dari 34 siswa itu artinya 55,8\% persen siswa masih belum tuntas, sedangkan kriteria ketuntasan minimal (KKM) 75 rata-rata memperoleh dibawah KKM yang telah ditetapkan oleh sekolah. Dibandingkan dengan siswa kelas VII A SMP Negeri 1 Monterado siswa yang memperoleh hasil belajar yang rendah hanya 6 dari 34 siswa itu artinya hanya 17,6\% siswa belum tuntas.

Sebagai upaya untuk meningkatkan hasil belajar tersebut, maka diperlukan suatu formula yang dapat memotivasi dan membangkitkan daya ingat siswa terhadap apa yang didengar dan dibaca dari bahan pelajaran yang diberikan oleh guru dengan pemberian metode belajar yang tepat dan efektif yaitu salah satunya dengan model pembelajaran Cooperative tipe Script.

\section{KAJIAN TEORI}

\section{Menyimak}

Tarigan (2008:30) mengatakan "Menyimak adalah suatu proses kegiatan mendengarkan lambanglambang lisan dengan penuh perhatian, pemahaman, apresiasi, serta memahami makna komunikasi yang telah disampaikan pembicara melalui ujaran atau bahasa lisan". Pendapat tersebut diperkuat oleh Subana (2011:213) yang mengatakan "Menyimak merupakan tingkatan mendengar yang paling tinggi karena selain mendengarkan, ada juga unsur pemahamannya".

\section{Dongeng}

Nurgiyantoro (2010:200) yang mengatakan bahwa "Dongeng merupakan suatu bentuk cerita rakyat yang bersifat universal yang dapat ditemukan diberbagai pelosok masyarakat dunia". Pada umumnya dongeng tidak terikah adanya tempat dan waktu. Selain itu dongeng bisa terjadi dinama saja dan kapan saja tanpa ada pertanggungjawaban pelataran. Dongeng merupakan bentuk cerita rakyat yang universal yang dapat ditemukan diberbagai pelosok masyarakat.

\section{Model Pembelajaran Cooperative tipe Script}

Menurut Huda (2013:32) mengatakan bahwa "Pembelajaran cooperative mengacu pada model pembelajaran di mana siswa bekerja sama dalam kelopok kecil dan saling membantu dalam belajar. Pernyataan tersebut diperkuat dengan pendapat Slavin (2009:4) yang mengatakan bahwa "Dalam kelas cooperative, para siswa diharapkan dapat saling membantu, saling mendiskusikan dan berargumentasi 
untuk mengasah pengetahuan yang mereka kuasai saat ini dan menutup kesenjangan dalam pemahaman masing-masing".

Dari pengertian di atas bahwa upaya meningkatkan keterampilan menyimak dongeng dengan menerapkan model Cooperative tipe Script merupakan suatu upaya yang akan penulis lakukan bersama guru dengan harapan dapat memperbaiki permasalahan yang terjadi dalam pembelajaran menyimak dongeng di kelas VII B SMP Negeri 1 Monterado. Penerapan model pembelajaran Cooperative tipe Script dalam pembelajaran menyimak dongeng lebih ditekankan pada strategi belajar, berarti melalui model pembelajaran Cooperative tipe Script siswa dibimbing untuk memahami materi pembelajaran menyimak dongeng dan membangun komunikasi yang baik sesama siswa dalam berdiskusi membahas berbagai pendapat yang dikemukakan dalam menanggapi wacana yang disimak.

\section{METODE PENELITIAN}

Jenis Penelitian dalam penelitian adalah deskriptif kualitatif. Arikunto, dkk. (2014:26) mengungkapkan bahwa "Metode deskriptif merupakan metode yang dimaksudkan untuk mengumpulkan informasi atau data tentang fenomena yang diteliti, misalnya kondisi sesuatu atau kejadian, disertai dengan informasi tentang faktor penyebab sehingga muncul kejadian yang dideskripsikan secara rinci, urut, dan jujur".

1. Bentuk Penelitian

Bentuk penelitian yang digunakan dalam penelitian ini adalah bentuk penelitian kualitatif deskriptif. Menurut Oktavia, W., \& Safrihady, S. (2016) Descriptive qualitative research is research that is intended to gather information about the status of an existing symptoms, the symptoms of circumstances according to what time of the study. Data yang dikumpulkan adalah data deskriptif berupa uraian kata-kata lisan, tulisan serta prilaku subjek yang diamati dan pengumpulan datanya sangat bergantung pada proses pengamatan penulis (Zuldafrial dan Lahir, 2011:21). Dengan demikian, dalam rencana penelitian ini akan dijelaskan mengenai peningkatan keterampilan menyimak dongeng dengan penerapan model pembelajaran Cooperative tipe Script pada siswa kelas VII B Sekolah Menengah Pertama Negeri 1 Monterado.

\section{Racangan Penelitian}

Rancangan penelitian ini menggunakan penelitian tindakan kelas. Menurut Natawijaya (Paizaluddin, 2013:2) menyatakan bahwa "Penelitian tindakan merupakan suatu bentuk penelaahan atau inkuiri melalui refleksi diri oleh penulis". Sedangkan penelitian tindakan kelas menurut Suwandi (2011:12) menyatakan bahwa "Penelitian tindakan kelas merupakan suau pencermatan terhadap kegiatan belajar berupa sebuah tindakan yang sengaja dimunculkan dan terjadi dalam sebuah kelas secara bersamaan". Berdasarkan pernyataan tersebut, berarti bahwa sebagai perencana dan pelaksana proses pembelajaran, guru dituntut selalu mengupayakan untuk memahami kondisi permasalahan di dalam kelas.

\section{Data dan Sumber Data}

a. Data

Data dalam rencana penelitian ini terdiri atas dua data yang sekaligus menjadi fokus penelitian, yakni proses pembelajaran menyimak dongeng dan hasil belajar siswa dengan penerapan model pembelajaran Cooperative tipe Script. Data diperoleh secara langsung dari proses pembelajaran menyimak dongeng dengan penerapan model pembelajaran Cooperative tipe Script pada siswa kelas VII B SMP Negeri 1 Monterado, Kecamatan Monterado, Kabupaten Bengkayang

b. Sumber Data

Sumber data dalam rencana penelitian ini diperoleh dari berbagai sumber yaitu sebagai berikut.

1) Ramlah, selaku guru mata pelajaran Bahasa Indonesia kelas VII B SMP Negeri 1 Monterado, sebagai pengimplementasi pembelajaran melalui penerapan model pembelajaran Cooperative tipe Script.

2) Siswa kelas VII B SMP Negeri 1 Monterado, yang berjumlah 34 siswa terdiri dari siswa laki-laki berjumlah 18 orang dan siswa perempuan berjumlah 16 orang, untuk mendapatkan data mengenai hasil belajar dan aktivitas siswa dalam proses pembelajaran. 
3) Dokumen atau arsip yang mencakup catatan hasil belajar, portofolio, kurikulum, Rencana Pelaksanaan Pembelajaran (RPP), foto dan hasil tes menyimak siswa kelas VII B SMP Negeri 1 Monterado.

4. Teknik dan Alat Pengumpul Data

a. Teknik Pengumpul Data

Sejalan dengan data yang akan dikumpulkan serta sumber data yang ada, selanjutnya akan dikemukakan mengenai teknik pengumpulan data. Teknik pengumpulan data adalah cara yang dapat digunakan oleh penulis untuk mengumpulkan data. Adapun tekni pengumpul data dalam penelitian ini adalah teknik observasi langsung, teknik komunikasi langsung dan teknik pengukuran

b. Alat Pengumpul Data

Alat pengumpul data yang digunakan dalam penelitian ini adalah panduan observasi, panduan wawancara, tes dan dokumentasi

5. Teknik Analisis Data

Teknik analisis data merupakan cara yang yang digunakan penulis untuk menganalisis data. Teknik analisis data yang digunakan dalam rencana penelitian ini yaitu teknik deskriptif komparatif dan teknik analisis kritis.

a. Teknik Deskriptif Komparatif

Teknik deskriptif komparatif digunakan untuk data kuantitatif. Suwandi, (2011:66) mengungkapkan bahwa "Teknik deskriptif komparatif digunakan untuk data kuantitatif, yakni dengan membandingkan hasil antar siklus". Peneliti membandingkan hasil sebelum penelitian dengan hasil akhir setiap siklus. Data kuantitaif dipakai untuk menganalisis data yang diperoleh dari hasil menyimak dongeng pada siklus I dan siklus II.

b. Teknik Analisis Kritis

Teknik analisis kritis digunakan untuk data kualitatif. Suwandi (2011:66) mengungkapkan "Teknik analisis kritis mencakup kegiatan untuk mengungkapkan kelemahan dan kelebihan kinerja siswa dan guru dalam proses belajar mengajar berdasarkan kriteria normatif yang diturunkan dari kajian teoretis maupun dari ketentuan yang ada". Hasil analisis tersebut dijadikan dasar dalam menyusun perencanaan tindakan untuk tahap berikutnya sesuai dengan siklus yang ada. Melalui analisis data kualitatif ini dapat diketahui peningkatan proses pembelajaran dan hasil pembelajaran melalui penerapan model pembelajaran Cooperative tipe Script

\section{HASIL PENELITIAN}

Pembelajaran menyimak dongeng meningkat dilakukan dalam dua siklus. Meningkatnya hasil pembelajaran keterampilan menyimak dongeng dibuktikan bahwa dalam pelaksanaan penelitian ini diperoleh dari hasil tindakan siklus I, dan siklus II. Setiap tahapan penelitian mulai dari pra tindakan, siklus I, dan Sikus II dalam meningkatkan keterampilan menyimak dongeng dengan penerapan model pembelajaran Cooperative tipe Script berjalan dengan baik melalui berbagai perbaikan pada setiap siklus sehingga mencapai tujuan pembelajaran yaitu meningkatkan keterampilan menyimak dongeng.

Dalam perencanaan pembelajaran siklus I terdapat 16 aspek yang menjadi pengamatan peneleiti. Dari 16 aspek yang diamati terdapat 1 aspek yang belum terpenuhi dalam penyusunan perencanaan pembelajaran yaitu. Selanjutnya aspek yang belum terpenuhi dalam perencanaan pembelajaran siklus I dapat terpenuhi pada rencana pelaksananaan pembelajaran siklus II.

Selanjutnya pada pelaksanaan pembelajaran 13 aspek yang menjadi pengamatan selama proses pembelajaran berlangsung dengan menggunakan lembar observasi pengamatan aktivitas guru dalam pelaksanaan pembelajaran. Dari hasil pengamatan pada siklus I menunjukkan 7 aspek tidak terpenuhi pada siklus I. Selanjutnya berdasarkan hasil refleksi siklus I terhadap pengamatan aktivitas guru pada proses pembelajaran siklus I diadakan perbaikan pada siklus II. Hasilnya tinggal 2 aspek yang tidak terpenuhi pada siklus II, namun hal ini sudah dapat dijadikan dasar peningkatan proses pembelajaran dilihat dari sisi kinerja guru dalam melaksanakan proses pembelajaran. 
Dalam pelakaksanaan pembelajaran peneliti juga mengamati aktivitas siswa selama proses pembelajaran berlangsung. Peneliti menggunakan lembar observasi aktivitas siswa selama proses pembelajaran berlangsung. Hasil observasi aktivitas siswa dalam proses pembelajaran menunjukkan peningkatan dilihat dari sisi efektifitas siswa dalam beraktivitas selama proses pembelajaran.

Selain pengamatan terhadap aktivitas siswa dalam proses pembelajaran, peneliti juga mengamati sikap siswa selama proses pembelajaran berlangsung baik itu dalam pelaksanaan pembelajaran siklus I maupun pembelajaran siklus II. Pengamatan terhadap sikap siswa dengan menggunakan lembar observasi sikap siswa selama proses pembelajaran.

Untuk mengetahui peningkatan hasil belajar menyimak dongeng siswa perlu adanya tes yang diberikan kepada siswa yang berhubungan dengan materi yang telah diberikan guru. Dari hasil tes menyimak dongeng pada siswa kelas VII B SMP N 1 Monterado menunjukkan adanya peningkatan hasil belajar siswa dari mulai pra tindakan sebelum menggunakan model pembelajaran Cooperative tipe Script, siklus I dan siklus II setelah menggunakan model pembelajaran Cooperative tipe Script.

Meningkatnya hasil nilai keterampilan menyimak dongeng pada siswa kelas VII B SMP Negeri 1 Monterado setelah menerapkan model pembelajaran Cooperative tipe Script dalam pembelajaran. Hal ini ditunjukan dengan adanya peningkatan nilai pada setiap siklus. Aspek-aspek yang dinilai dalam menyimak dongeng adalah struktur teks dongeng, kelengkapan unsur intrinsik dongeng yaitu menemukan tema, penokohan,karakter tokoh, latar, pesan. Peningkatan keterampilan menyimak dongeng akan dijelaskan secara keseluruhan mulai dari pra tindakan, siklus I, dan siklus II dapat dilihat pada Tabel 1 sebagai berikut.

Tabel 1. Hasil Keseluruhan Tindakan

\begin{tabular}{llcccc}
\hline No & \multicolumn{1}{c}{ Siklus } & $\begin{array}{c}\text { Jumlah } \\
\text { Siswa }\end{array}$ & \multicolumn{2}{c}{ Nilai } & $\begin{array}{c}\text { Nilai Rata- } \\
\text { rata }\end{array}$ \\
\hline 1 & Pra tindakan & 34 & 19 Siswa & 15 Siswa & 65,9 \\
2 & Siklus I & 34 & 11Siswa & 23 Siswa & 73,6 \\
3 & Siklus II & 34 & 5 Siswa & 29 Siswa & 80,0 \\
\hline
\end{tabular}

Berdasarkan keseluruhan hasil mulai dari tindakan pada siklus I hingga siklus II di atas dapat disimpulkan bahwa hasil belajar siswa pada materi menyimak dongeng pada siswa kelas VII B SMP Negeri 1 Monterado dengan KKM 75 dari setiap tindakan penelitian terdapat peningkatan. Hal ini dapat dilihat dari peningkatan nilai rata-rata siswa pada saat menggunakan model pembelajaran Cooperative tipe Script 73,6 pada siklus I dengan menggunakan model pembelajaran Cooperative tipe Script dan meningkat dengan perolehan rata-rata 80,0 pada siklus II dengan menggunakan model pembelajaran Cooperative tipe Script. Persentase ketuntasan belajar siswa secara klasikal mengalami peningkatan. Sebelum diterapkannya model pembelajaran Cooperative tipe Script jumlah siswa yang tuntas atau mencapai KKM adalah 15 siswa (44,1\%), dan setelah menerapkan model pembelajaran Cooperative tipe Script pada siklus I siswa yang tuntas atau mencapai KKM berjumlah 23 siswa $(67,7$ $\%$ ), dan pada siklus II siswa yang tuntas atau mencapai KKM berjumlah 29 siswa (85,2 \%). Dengan adanya peningkatan ketuntasan belajar siswa tersebut, dapat disimpulkan bahwa model pembelajaran Cooperative tipe Script dapat meningkatkan keterampilan menyimak dongeng pada siswa kelas VII B SMP Negeri 1 Monterado.

\section{SIMPULAN}

Kesimpulan hasil perencanaan pembelajaran dalam penelitian ini adalah mempersiapkan segala hal yang mendukung terlaksanya pembelajaran yang efektif dan efisien. Adapun hal yang disiapkan dalam 
penelitian ini adalah (a). Menentukan jadwal yang dilaksanakan antara peneliti dan kolaborator untuk membahas rencana kegiatan yang akan dilaksanakan (b). Menentukan materi pelajaran (c). Membuat langkah-langkah pembelajaran (d). Menentukan model pembelajaran (e). Menentukan media pembelajaran

Penerapan model pembelajaran Cooperative tipe Script dalam penelitian tindakan kelas dapat meningkatkan kualitas proses pembelajaran menyimak dongeng. Hal ini dibuktikan dengan peningkatan kemampuan guru dalam mengelola pembelajaran, dan kegiatan dalam partisipasi siswa mengikuti proses pembelajaran. Kinerja guru dalam mengelola pembelajaran pun terus meningkat dari $46,1 \%$ pada siklus I menjadi $84,7 \%$ pada siklus II. Nilai kegiatan aktivitas siswa di kelas mengikuti proses pembelajaran pada siklus I mencapai $64,7 \%$ meningkat menjadi $88,2 \%$ pada siklus II.

Penerapan model pembelajaran Cooperative tipe Script dapat meningkatkan keterampilan menyimak dongeng pada siswa kelas VII B SMP Negeri 1 Monterado. Peningkatan hasil belajar siswa dapat diketahui setelah membandingkan hasil pra tindakan, siklus I, dan siklus II. Nilai rata-rata yang diperoleh siswa pada pra tindakan adalah 65,9 berada dalam kategori kurang, pada siklus I rata-rata nilai 73,6 berada dalam kategori cukup, dan pada siklus II 88,0 berada dalam kategori baik dan mencapai pada peningkatan yang diharapkan.

\section{Daftar Pustaka}

Arikunto, Suharsimi. dkk. (2014). Penelitian Tindakan Kelas. Jakarta : PT Bumi Aksara.

Hamdani. (2011). Strategi Belajar Mengajar. Bandung: CV Pustaka Setia.

Huda, Miftahul. (2013). Cooperative Learning. Yogjakarta : Pustaka Pelajar.

Miftahul A'la. (2011). Quantum Teaching. Yogyakarta: Diva Pers.

Nurgiyantoro, Burhan. (2010). Sastra Anak Pengantar Pemahaman Dunia Anak. Yogyakarta: Gadjah Mada University Press

Oktavia, W. (2015). Inovasi Model Partisipasi Solusi (Partisol) untuk Meningkatkan Keterampilan Berbicara Siswa.

Oktavia, W., \& Safrihady, S. (2016). Teacher Role In Formation Politeness Of Student Learning Process. JETL (Journal Of Education, Teaching and Learning), 1(2), 95-98.

Paizaluddin dan Ermalinda. (2013). Penelitian Tindakan Kelas. Bandung : Alfabeta.

Slavin, Robert, E. (2009). Cooperative Learning. Bandung : Nusa Media.

Subana, Sunarti. (2011). Strategi Belajar Mengajar Bahasa Indonesia. Bandung : CV Pustaka Ceria.

Sugiyanto.(2013). Model-Model Pembelajaran Inovatif. Surakarta: Yuma Pustaka.

Susanto, H., \& Sunarsih, E. (2015). Model Pembelajaran Cooperative Tipe Script sebagai Upaya Meningkatkan Keterampilan Menyimak Dongeng Siswa SMP.

Suwandi, Sarwiji. (2011). Penelitian Tindakan Kelas (PTK) \& Penulisan Karya Ilmiah. Surakarta : Yuma Pustaka.

Suyatno. (2009). Menjelajah Pembelajaran Inovatif. Surabaya: Masmedia Buana Pustaka.

Tarigan, Henry. Guntur. (2008). Menyimak Sebagai Suatu Keterampilan Berbahasa. Bandung : Angkasa.

Zuldafrial dan Lahir.M. (2012). Penelitian Kualitatif. Surakarta: Yuma Pustaka. 